Research article

\title{
Pharmacognostical studies on Saraca asoca (Roxb.) Willd. flower
}

\author{
Anupam Bisht $^{1}$, Saba Irshad ${ }^{2}$, A. K. S. Rawat ${ }^{3}$ and Harinath Dwivedi ${ }^{1}$ \\ ${ }^{1}$ School of Pharmacy, Babu Banarasi Das University, Faizabad Road, Lucknow-226028, India \\ ${ }^{2}$ Phytoinformatics Department, CSIR- Unit for research \& development of information products, \\ Pune-411008, India \\ ${ }^{3}$ Pharmacognosy and Ethnopharmacology Division, CSIR-National Botanical Research Institute, \\ Lucknow-226001, India
}

*Corresponding Author: anupam_sajwan@yahoo.com

[Accepted: 12 April 2017]

\begin{abstract}
Saraca asoca is a medium sized handsome evergreen tree of Caesalpiniaceae family. It is distributed in the central and eastern Himalayas and Kashi, Garo and Lushai hills. It is used in folk medicine for the treatment of many diseases. Bark is useful in menorrhagia, leaves have blood purifying properties and seeds are used for treating bone fractures and vesical calculi. Flowers of S. asoca are considered to be uterine tonic and used in dysentery and dried flowers are used in diabetes. The aim of present study was to investigate pharmacognostical and phytochemical profile of $S$. asoca flower. Powder microscopy of flower showed covering trichomes, spiral xylem vessels, oval-spherical pollen grains, oil gland, prismatic crystals and minute starch grains. $\beta$ sitosterol, a phytosterol was identified at Rf 0.80 and quantified to $0.06 \%$ in the flower. Phytochemically the plant was found to contain flavonoids, glycosides, saponins, phenolics and tannins.
\end{abstract}

Keywords: Microscopy - HPTLC - Standardization - Phytochemical profile.

[Cite as: Bisht A, Irshad S, Rawat AKS, Dwivedi H (2017) Pharmacognostical studies on Saraca asoca (Roxb.) Willd. flower. Tropical Plant Research 4(1): 153-160]

\section{INTRODUCTION}

Saraca asoca (Roxb.) Willd. = Saraca indica L. of Caesalpiniaceae family is medium sized handsome evergreen tree up to $9 \mathrm{~m}$. in height. It is found throughout India in evergreen forests up to an altitude of $750 \mathrm{~m}$. in the central and eastern Himalayas and Kashi, Garo and Lushai hills. The branches of the tree are glabrous and drooping. The leaves are $30-60 \mathrm{~cm}$. in length, in 2-3 pairs of lanceolate leaflets. The flowers are fragrant, orange-yellow in colour and found in dense corymbs (Anonymous 2005). Ashoka bark is bitter, acrid, refrigerant, astringent to the bowels, cures dyspepsia, enlargement of the abdomen, piles and ulcers (Kirtikar \& Basu 1975). Bark is useful in menorrhagia due to uterine fibroids, in internal bleeding hemorrhoids and hemorrhagic dysentery (Nadkarni 1982). Leaves have blood purifying properties and their juice mixed with cumin seeds is used for stomach-ache. Flowers of $S$. asoca are considered to be uterine tonic and used in dysentery, scabies, syphilis, burning sensation and in hemorrhoids. Dried flowers are used in diabetes. Seeds are used for treating bone fractures and vesical calculi (Warrier et al. 1997). Pharmacologically the plant have been reported to possess, antibacterial (Acharyya et al. 2009), analgesic (Verma et al. 2010, Mohod et al. 2014), anticancer (Kaur \& Misra 1980, Ghosh et al. 1999, Cibin et al. 2012), antiulcer (Maruthappan et al. 2010), oxytocic (Satyavati et al. 1970), anti-inflammatory (Shelar et al. 2010), anthelmintic (Sarojini et al. 2011) and larvicidal activity (Mathew et al. 2009). Reported phytoconstituents from S. asoca bark are catechin, epicatechin, procyanidin B2, leucocyanidin and epiafzelechin- $(4 \beta \rightarrow 8)$-epicatechin. Leaves contain quercetin, $\beta$ sitosterol, gallic acid and ellagic acid. Flowers contained oleic, palmitic, linoleic acid, quercetin, gallic acid and ellagic acid. Seeds have been reported to contain various fatty acids such as oleic, linoleic, palmitic and stearic acid (Chatterjee \& Pakrashi 2006). The most important and widely used part of the ashoka plant is its bark, flowers are another important ingredients in many ashoka herbal formulations. Literature survey on this plant revealed pharmacognostic and pharmacological details on stem bark but on the flowers there is minimal 
information on pharmacological and pharmacognostical work.

Therefore, the objective of present study is to investigate macroscopical, microscopical characters, physicochemical parameters, preliminary phytochemical screening, fluorescence analysis and HPTLC fingerprinting of the Saraca asoca flowers and standardize the raw drug on the basis of pharmacognostical and phytochemical studies.

\section{MATERIALS AND METHODS}

\section{Plant material}

The flowers of Saraca asoca (Roxb.) Willd. were collected from the Central Institute of Medicinal \& Aromatic Plants, Lucknow in the month of April 2015 and was identified by Botanical survey of India (BSD) Northern Regional Centre, Dehradun as S. asoca Accession number 115720. A herbarium of this plant was deposited in the herbarium of Botanical Survey of India, Northern Regional Centre, Dehradun (BSD). The flowers were dried in shade, powdered and stored in air tight container for further studies.

\section{Macroscopical studies}

Macroscopical studies helps in the evaluation of raw drug. The fresh flowers of $S$. asoca were washed thoroughly under tap water to remove adhering dirt. The flowers were morphologically evaluated for external characters such as colour, size, shape, odour, taste and texture etc.

\section{Microscopic studies}

Plant drugs are generally used in powder form. In the powdered form generally histological structures destroyed hence powder drug study is essential. For powder drug study, the dried flowers were grinded in pestle-mortar then passed through 60 mesh sieve. The fine powder was mounted in chloral hydrate and glycerin solution (1:1) and slides were prepared (Jackson \& Snowdon 2000). Slides were observed under microscope at 15x 10x magnification. The cell structures were observed under microscope and drawn by the help of Camera lucida. Photomicrographs were taken with Leica USA (Leica 2000 ATC model) Digi 3 Photomicrographic unit at 10x 40x magnification.

\section{Physico-chemical studies}

Physico-chemical constants like ash values, extractive values, moisture content and foaming index were determined as per prescribed methods (Anonymous 1996).

\section{Fluorescence analysis}

Fluorescence analysis was done according to the prescribed method (Mukherjee 2002). Powder sample was treated with different chemical reagents and observed under different UV range and visible light for various colour reactions.

\section{Preliminary phytochemical screening}

Dried, coarsely powdered flowers of Saraca asoca was extracted successively with petroleum ether (60$80^{\circ} \mathrm{C}$ ), chloroform, acetone, methanol and water using soxhlet apparatus. Extracts thus obtained were concentrated under reduce pressure to get different extracts. Further these extracts were screened for the presence of various phytoconstituents (Khandelwal 2004).

\section{HPTLC studies}

For HPTLC fingerprinting, methanolic extract was prepared by extracting $2 \mathrm{~g}$ of the powdered flowers of Saraca asoca with $10 \mathrm{ml}$ methanol by maceration at room temperature. The procedure was repeated thrice with methanol $(10 \mathrm{ml})$ at room temperature. All the extracts were combined, filtered through Whatmann No.1 filter paper. The combined filtrate were concentrated under vacuum in a rotary evaporator at $40^{\circ} \mathrm{C} .10 \mathrm{mg}$ of this dried extract was redissolved in $1 \mathrm{ml}$ of methanol. Stock solution of standard marker $\beta$-sitosterol was prepared by dissolving $1 \mathrm{mg} \beta$-sitosterol in $10 \mathrm{ml}$ methanol to get $0.1 \mathrm{mg} \cdot \mathrm{ml}^{-1}$ solution of standard marker.

Chromatography was performed on Merck HPTLC precoated Silica gel G60 $F_{254}$ (10x10) TLC plate of uniform thickness of $0.2 \mathrm{~mm}$. $15 \mu \mathrm{l}$ of sample and $10 \mu \mathrm{l}$ of standard were applicated with Camag Linomet V sample applicator on Plate. The plate was developed to a distance of $8 \mathrm{~cm}$ from the lower edge of the plate in solvent system Toluene: Ethyl acetate: Formic acid (7:3:1). The plate was visualized under UV $254 \mathrm{~nm}$, UV 366 $\mathrm{nm}$ and under visible light after dipping in anisaldehyde-sulphuric acid reagent followed by drying and heating at $110^{\circ} \mathrm{C}$ for 5 minutes in order to develop the chromatogram. The plate was documented in visible light after 
derivatization (Wagner \& Bladt 1996).

\section{RESULTS}

Macroscopic features

Flowers of Saraca asoca orange or orange- yellow in colour, aromatic, astringent in taste, found in dense axillary corymb inflorescence. Hermaphrodite flowers, $2.5-3.5 \mathrm{~cm}$ in length. Ovate bracts and 2 sub acute bracteoles, appearing like a calyx; petaloid 4 tubular calyx, imbricate, yellowish orange- red in colour; corolla absent; stamens 6-7, exerted, long filiform filament, versatile anther; minute capitate stigma, style curved into ring and ovary pubescent (Fig. 1).
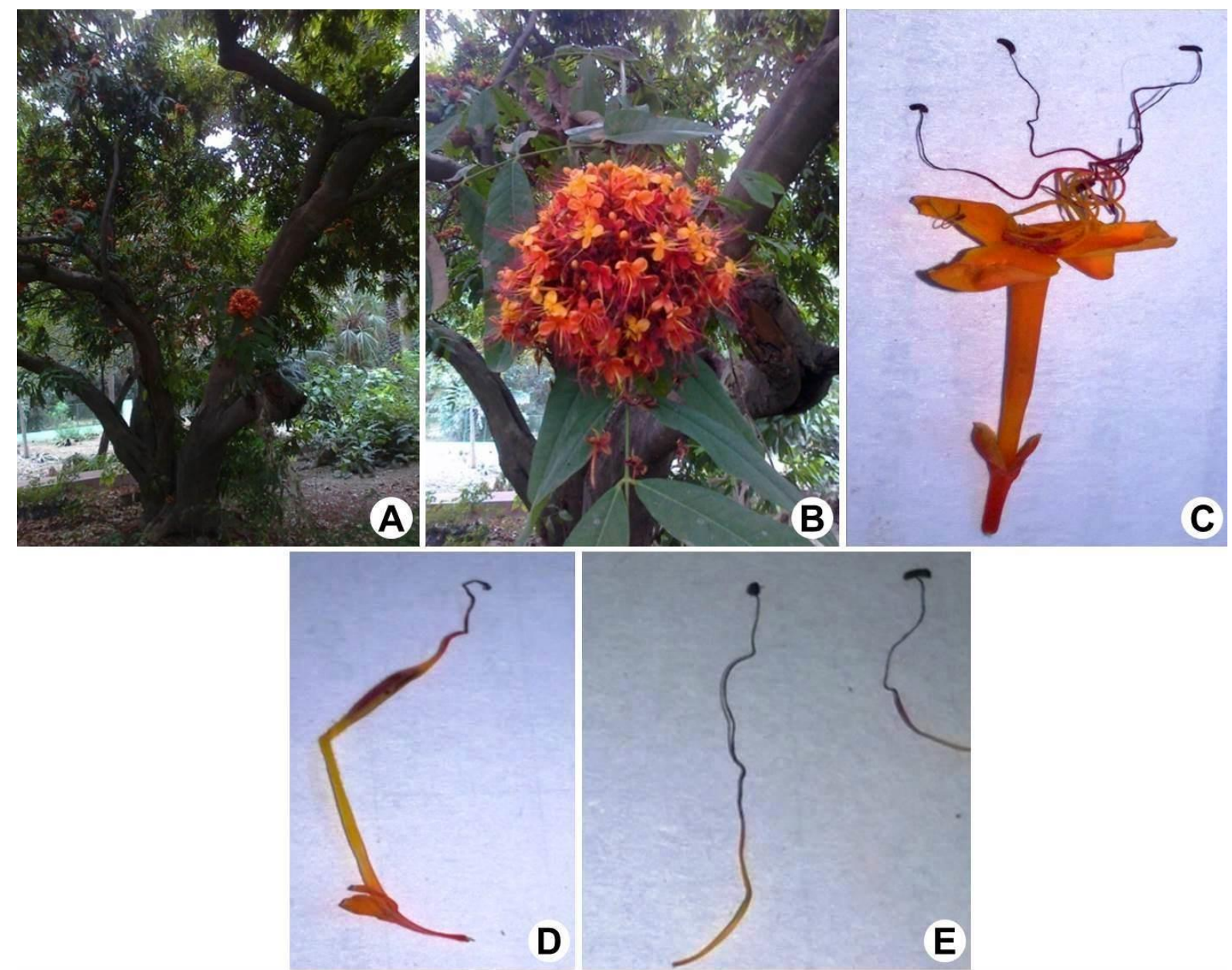

Figure 1. Different parts of Saraca asoca: A, Tree habit; B, A flowering twig; C, A flower; D, Gynoecium; E, Stamens

Microscopic studies

The powder was brown in colour with aromatic odour, astringent in taste. Under microscopic observation powder showed uniseriate, small covering trichomes present on the outer epidermis of calyx. Pollen grains were large, oval to spherical in shape with smooth exine. Small brown ovoid oil gland, stomata, prismatic crystals of calcium oxalate were present. Spiral xylem vessels observed and epidermal cells of calyx were rectangular in surface view. Fragments of fibrous layer of anthers were composed of small cells. The occasional fragments of the walls of ovary were composed of small polygonal cells. Minute starch grains were scattered into the powder (Figs. 2-3).

\section{Physico-chemical studies}

Various physico-chemical parameters viz. total ash, acid insoluble ash, water soluble ash, water soluble extractive, alcohol soluble extractive, moisture content and foaming index were determined according to Indian Pharmacopoeia (Anonymous 1996) and results are given in (Table 1). Water soluble extractive value of S. asoca is found to be higher in comparison to alcohol soluble soluble extractive value which denotes the possibilities of presence of higher amount of polar water soluble constituents in the flower of $S$. asoca. Ash values are important quantitative standard and it denotes the inorganic components and impurities present in drugs. Total www.tropicalplantresearch.com 
ash value and acid insoluble ash of $S$. asoca were found low which indicate low content of carbonates, phosphates, silicates and silica and low contamination with silicon material or sand. Moisture content determination is important for maintaining the pharmacopoeial standards and it indicates the stability of the drug. Foaming index is found less than 100 and it denotes the foaming ability of drugs.

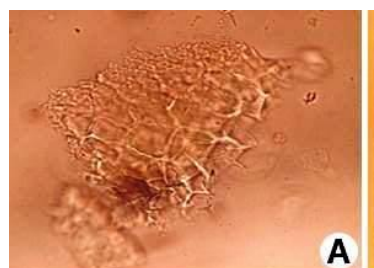

A

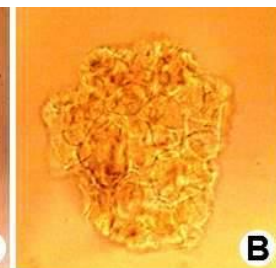

B

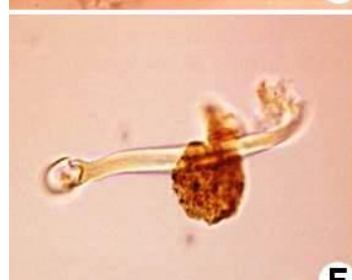

$\mathbf{F}$

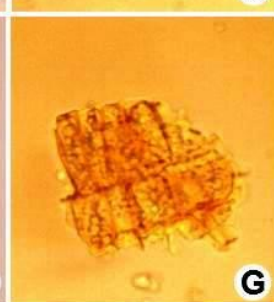

G

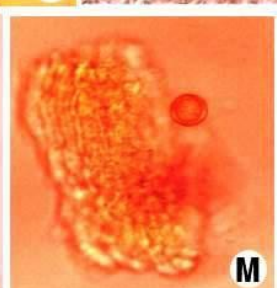

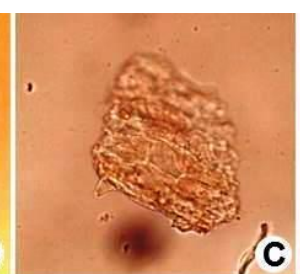

C

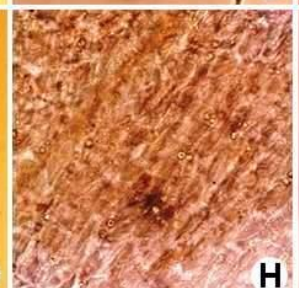

H

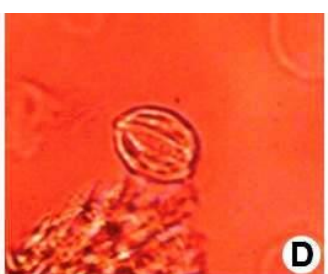

D

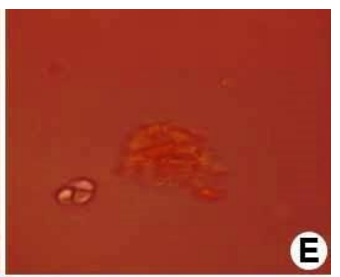

I
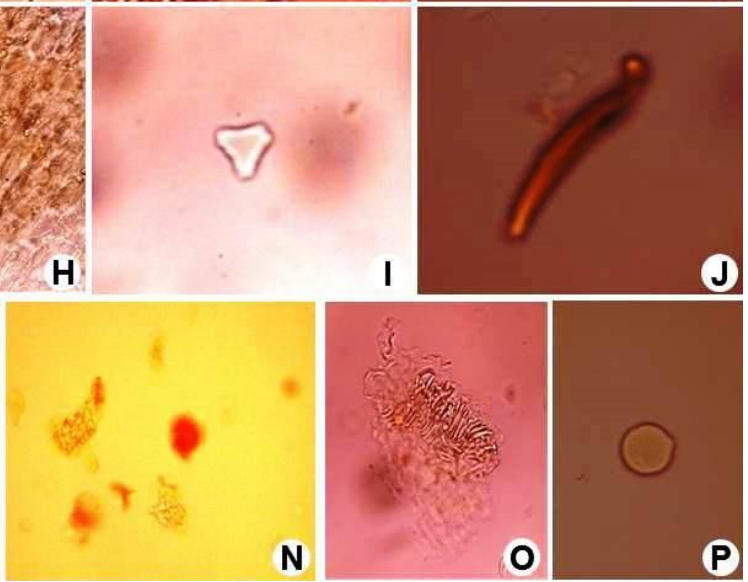

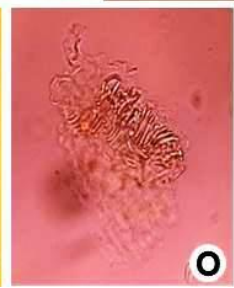

(

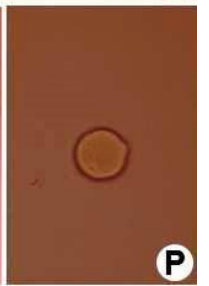

Figure 2. Powder microscopy of flower of Saraca asoca (at 10x 40x magnification): A, Epidermal cells in surface view; B, Epidemal cells of calyx form a disk; C, Outer epidermis of bract with trichomes; D, Stomata; E, Starch grains; F, Covering trichome ; G, Upper epidermis of calyx showing palisade cells; H, Outer epidermis near the base of bracteoles in surface view showing calcium oxalate crystals; I, Prismatic crystal of calcium oxalate; J, Part of gynoecium showing stigma and style; K, Parenchymatous cells; L, Xylem vessels with spiral thickening; M, Oil gland; N, Part of ovary; O, Endothecium of anther; $\mathbf{P}$, Pollen grains.

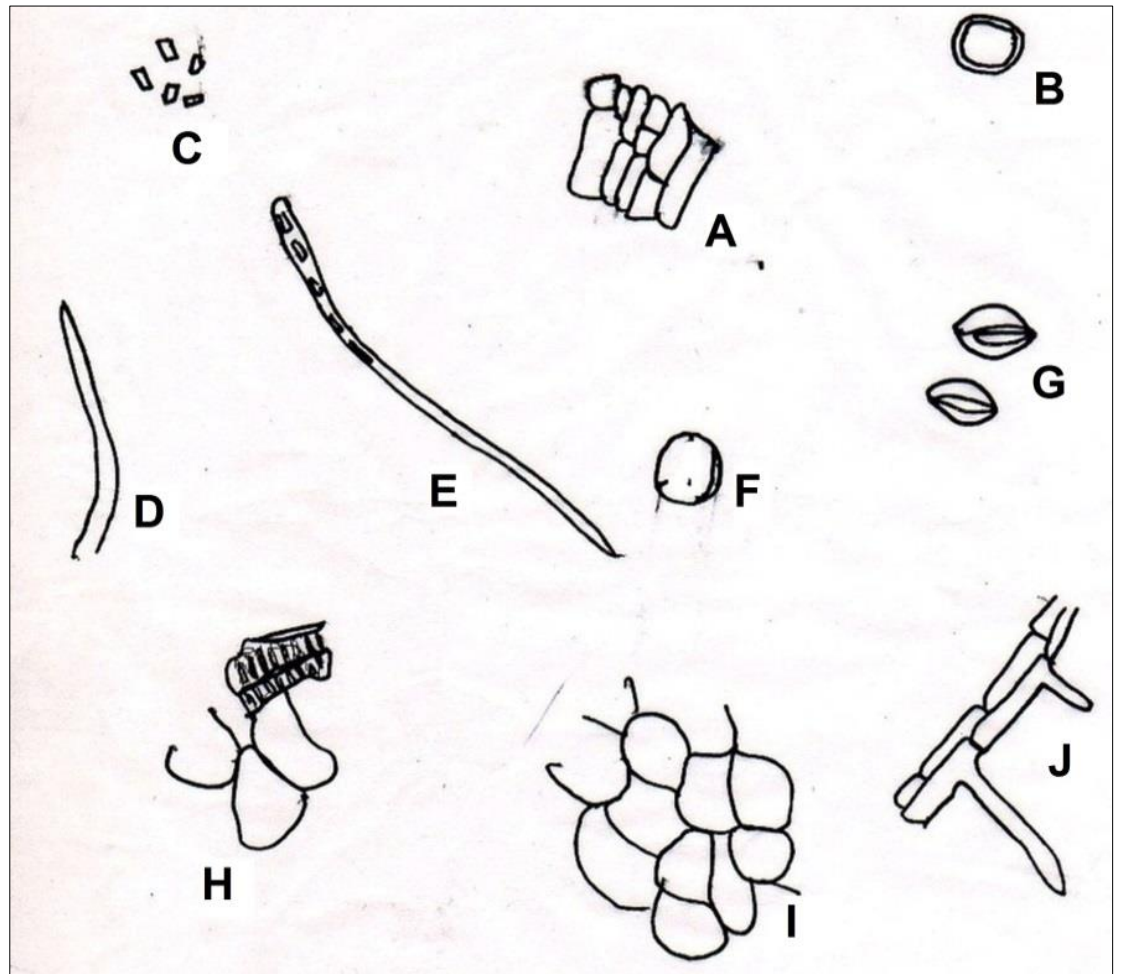

Figure 3. Microscopic examination of powdered flower of Saraca asoca with camera lucida (at 15x 10x magnification): A, Epidermal cells in tangential view; B, Oil gland; C, Prismatic crystals of calcium oxalate; D \& E, Covering trichome; F, Pollen grain; G, Stomata; H, Spiral xylem vessels; I, Epidermal cells of calyx in surface view; J, Trichomes with epidermal cell. 
Table 1. Quantitative standards for the flower of Saraca asoca.

\begin{tabular}{ll}
\hline Parameters & Mean \pm SD \\
\hline Ash Values & \\
(i) Total ash & $4.73 \pm 0.20$ \\
(ii) Acid-insoluble ash & $0.23 \pm 0.03$ \\
(iii) Water-soluble ash & $2.5 \pm 0.25$ \\
& \\
Extractive Values & \\
(i) Alcohol soluble & $7.0 \pm 1.50$ \\
(ii) Water soluble & $24.33 \pm 0.76$ \\
& \\
Moisture content & $68.13 \pm 6.34$ \\
Foaming index & Less than 100 \\
\hline
\end{tabular}

Fluorescence analysis

Many herbs fluorescence when cut surface or powder is exposed to UV light and this can help in their identification. For a few drugs (Rhapontic, Indian and Chinese rhubarb) it is used for identification when they are in powdered form. Many phytochemicals present in plant materials shown fluorescence when examined under UV light. For each compound the colour of fluorescence is specific. Powdered drug was treated with different reagents and was examined under UV light $(254 \& 366 \mathrm{~nm})$. The $S$. asoca powder treated with different reagents shown no fluorescence when examined under UV light (254 \& $366 \mathrm{~nm}$ ) but the distinctive colour changes in treated powder observed under UV light examination and the results are given in (Table 2).

Table 2. Florescence analysis of the powdered flower of Saraca asoca.

\begin{tabular}{llll}
\hline Treatment & Day light & Short UV light (254 nm) & Long UVlight (365 nm) \\
\hline Powder as such & Chocolate brown & Dark brown & Dark brown \\
Powder $+1 \mathrm{~N} \mathrm{NaOH}$ & Rust brown & Black & Black \\
Powder $+\mathrm{CH}_{3} \mathrm{COOH}$ & Chocolate brown & Dark chocolate & Dark chocolate \\
Powder $+1 \mathrm{~N} \mathrm{HCl}$ & Light brown & Black & Black \\
Powder $+\mathrm{Cocn} . \mathrm{NH}_{3}$ & Brownish-orange & Rusty brown & Blackish-brown \\
Powder $+50 \% \mathrm{H}_{2} \mathrm{SO}_{4}$ & Brown & Brown & Dark brown \\
Powder+Conc. $\mathrm{HNO}_{3}$ & Brown & Brownish-green & Blackish-green \\
\hline
\end{tabular}

Table 3. Successive soxhlet extractive values of Saraca asoca flower.

\begin{tabular}{llll}
\hline Extract & Colour & Nature & Value $($ Mean \pm SD) \\
\hline Petroleum ether & Yellow & Waxy & $1.57 \pm 0.14$ \\
Choloroform & Light green & Waxy & $1.13 \pm 0.09$ \\
Acetone & Yellowish-brown & Sticky & $1.70 \pm 0.16$ \\
Methanol & Rusty brown & Viscous & $9.42 \pm 0.90$ \\
Water & Blackish-brown & Gummy & $9.11 \pm 0.95$ \\
\hline
\end{tabular}

Table 4. Preliminary detection of phytoconstituents in the flower of Saraca asoca

\begin{tabular}{llllll}
\hline \multirow{2}{*}{ Phytoconstituents } & \multicolumn{5}{c}{ Extracts } \\
\cline { 2 - 6 } & Petroleum ether & Chloroform & Acetone & Alcohol & Water \\
\hline Sterols & + & + & - & - & - \\
Carbohydrates & - & - & + & + & + \\
Glycosides & - & - & + & + & + \\
Phenolic \& Tannins & - & - & - & + & + \\
Flavonoids & - & - & + & + & + \\
Saponins & - & - & - & - & + \\
Alkaloids & - & - & - & - & - \\
\hline
\end{tabular}

Note: $+=$ Present; - = Absent.

\section{Preliminary phytochemical studies}

The percentage successive soxhlet extractive values of the raw drug with different solvents (solvents used according to increasing polarity order) were determined with reference to the air dried drug. The extractive value of different flower extracts of $S$. asoca along with colour and nature of extract is given in (Table 3 ). The results showed that the $\%$ yield of extract increases as solvent polarity increased and maximum yield was obtained in methanol solvent. The Phytochemical analysis of different solvent extracts of $S$. asoca flower www.tropicalplantresearch.com 


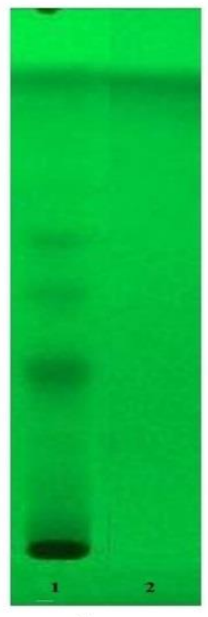

A

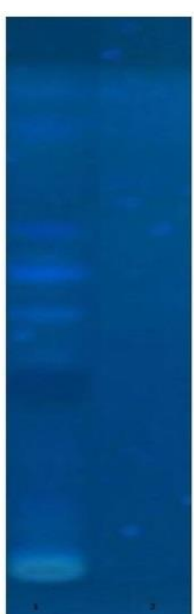

B

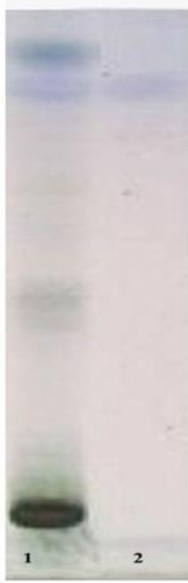

C

Figure 4. TLC Profile of methanolic extract of Saraca asoca: A, Visualization under UV $254 \mathrm{~nm}$; B, Under UV $366 \mathrm{~nm}$; C, Under visible light after derivatization. 1, Saraca asoca 2 . $\beta$ - sitosterol.
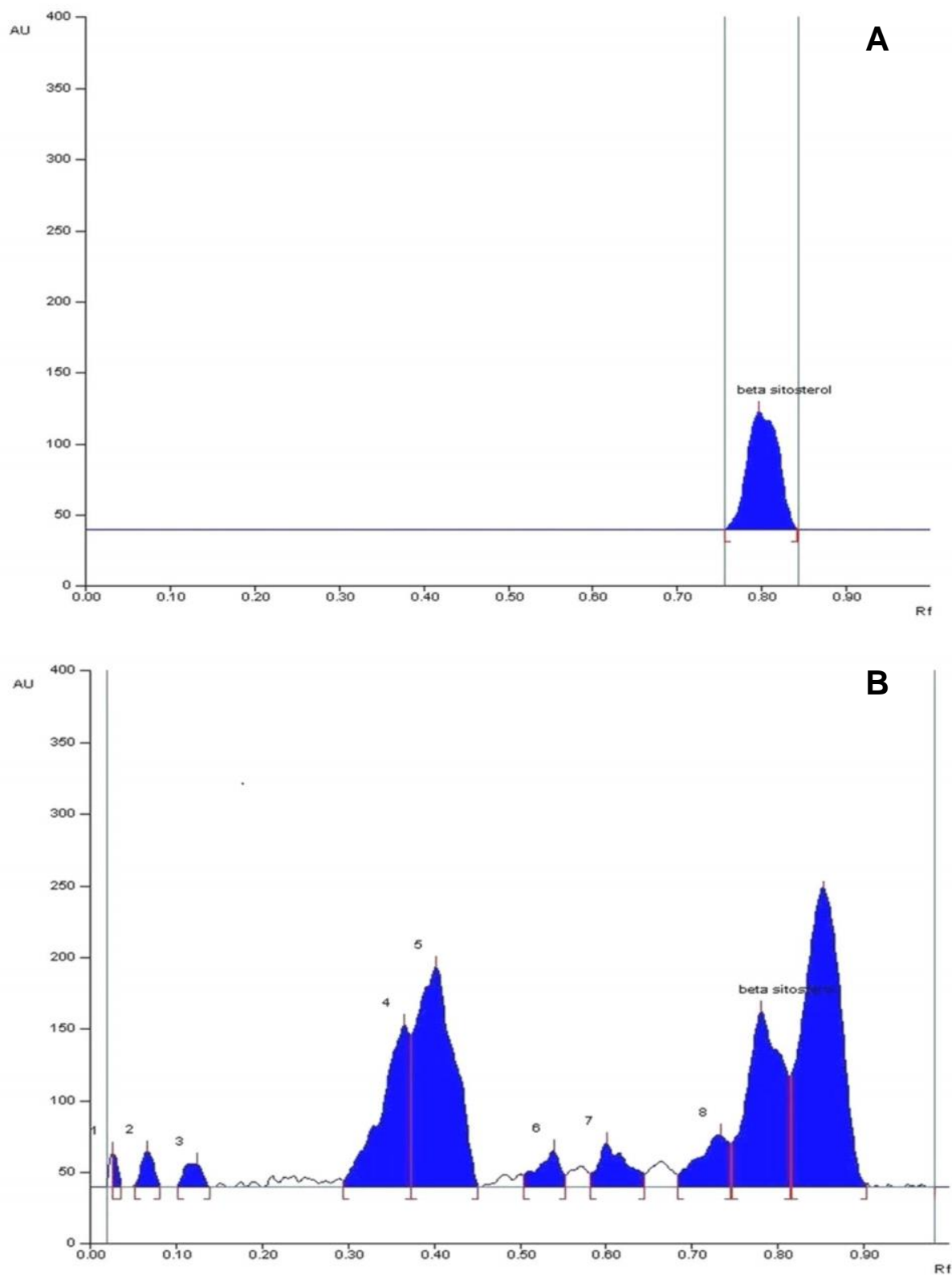

Figure 5. HPTLC Densitogram: A, Area under curve of standard beta sitosterol at $600 \mathrm{~nm}$; B, HPTLC chromatogram of Saraca asoca showing beta sitosterol at $600 \mathrm{~nm}$. 
showed the presence of carbohydrates in acetone, alcohol and water extracts. Phenolic compounds and tannins were present in alcohol and water extracts, flavonoids in acetone, alcohol and water extracts, saponins in water extracts, glycosides in acetone, alcohol and water extract, sterol in petroleum ether and chloroform extracts only. These extracts exhibit negative tests for alkaloids. Results are shown in (Table 4).

\section{HPTLC finger print profile}

Quantitative HPTLC analysis of $\beta$-sitosterol in ethanolic extract of $S$. asoca has been performed. A densitogram and banding pattern obtained from extract shows $\beta$-sitosterol $0.06 \%$. Rf value of $\beta$-sitostetrol was recorded 0.80 (Fig. 4-5).

\section{DISCUSSION}

The purpose of standardization of raw drugs is to ensure its therapeutic efficacy. Standardization ensures the use of correct herbs and determines its quality. S. asoca flower was standardized on the basis of macroscopic, microscopic studies, physico-chemical standards, fluorescence analysis and HPTLC. Microscopic studies give detailed information about the raw drugs by identifying the known histological characters of the drugs. For the powdered drug identification is based on presence or absence of different cytomorphological characters viz. parenchyma, collenchyma, fibres, stones cells, vessels, trichomes, secretory cells, epidermal cells and the cell inclusion characteristics viz. starch grains, pollen grains aleurone grains, calcium-oxalate crystals. Moisture content determination is important for denoting the stability of raw drug as excess water in raw drugs favours spoilage of drugs by molds and bacteria and make possible the enzymatic destruction of active principles. Most drugs may be stored safely if the moisture content is reduced to 6 per cent or less (Mukherjee 2002). Ash values denote the inorganic materials phosphates, metallic salts and silica present in raw drugs and it is important parameter for determination of quality, purity and detection of adulteration in raw drugs. Extractive values indicate the nature of constituents present in a raw drug. Such extractive values provide an indication of the extent of polar, medium polar and non-polar components present in the plant material. The preliminary phytochemical screening gives the general idea regarding the nature of chemical constituents present in raw drugs and it is useful in finding the quality of the drug (Kokate 1999). Many medicinal plants contain saponins and their aqueous decoction on shaking produces persistent foam. Foaming index measures the foaming ability of an aqueous decoction of plant materials (Anonymous 1998). Fluorescence analysis is an important standardization parameter. Few drugs viz. ergot powder, berberis, gentian, aconitine gives specific fluorescence when exposed to UV light. A nonfluorescent compound may produce fluorescence if they are mixed with fluorescent impurities (Ansari 2006, Nawagish et al. 2007). Various physico-chemical parameters, viz. moisture content, ash values, extractive values, foaming index, HPTLC, fluorescence analysis and phytochemical screening of various extracts were performed to substantiate standardization data on the flower of Saraca asoca. These parameters help in the evaluation of purity of drugs. The present study concludes that the complete pharmacognostic parameters of the flower of $S$. asoca would be useful in identifying the flowers for safe applications in drug manufacturing.

\section{ACKNOWLEDGEMENTS}

Authors duly acknowledge Dr. Sayyada Khatoon, Scientist, Pharmacognosy and Ethnopharmacology Division, N.B.R.I, Lucknow for their kind help.

\section{REFERENCES}

Acharyya S, Patra A \& Bag PK (2009) Evaluation of the antimicrobial activity of some medicinal plants against enteric bacteria with particular reference to multidrug resistant Vibrio cholera. Tropical Journal of Pharmaceutical Research 8(3): 231-237.

Anonymous (1996) Indian Pharmacopoeia, Vol 2. Controller of Publications, Ministry of Health and Family Welfare, Government of India, New Delhi, pp. A48-A99.

Anonymous (1998) Quality control methods for medicinal plant materials. WHO, Geneva, pp. 46.

Anonymous (2005) The Wealth of India: A Dictionary of Indian Raw Materials and Industrial Products, Vol 9. CSIR, New Delhi, pp. 231.

Ansari SH (2006) Essentials of Pharmacognosy, $I^{\text {st }}$ edition. Birla Publications, New Delhi.

Chatterjee A \& Pakrashi SC (2006) The Treatise on Indian Medicinal Plants, Vol 2. National Institute of Science Communication, CSIR, New Delhi, pp. 46-47. 
Cibin TR, Devi DG \& Abraham A (2012) Chemoprevention of two-stage skin cancer in vivo by Saraca asoca. Integrative Cancer Therapies 11: 279-286.

Ghosh S, Majumder M, Majumder S, Ganguly NK \& Chatterjee BP (1999) Saracin: a lectin from Saraca indica seed integument induces apoptosis in human T-lymphocytes. Archives of Biochemistry and Biophysics 371: $163-168$.

Jackson BP \& Snowdon DW (2000) Atlas of Microscopy of Medicinal Plants, Culinary Herbs and Spices. CBS Publishers and Distributors, New Delhi, pp. 154-188.

Kaur JD \& Misra K (1980) Biological and pharmacological activity of Saraca asoca: anticancer activity. Journal of Indian Chemical Society 57(12): 1243.

Kokate CK, Purohit AP \& Gokhale SB (1999) Pharmacognosy, $12^{\text {th }}$ edition. Nirali Prakashan, pune, pp. 80-82.

Khandelwal KR (2004) Practical Pharmacognosy-Techniques and Experiments, $12^{\text {th }}$ edition. Nirali Prakashan, Pune, pp. 149-156.

Kirtikar KR \& Basu BD (1975) Indian medicinal plant. International Book Distributors, Dehradun, India.

Maruthappan V \& Sakthi SK (2010) Antiulcer activity of aqueous suspension of S. indica flower against gastric ulcers in albino rats. Journal of Pharmacy Research 3(1): 17.

Mathew N, Anitha MG, Bala TS, Sivakumar SM, Narmadha R \& Kalyanasundaram M (2009) Larvicidal activity of Saraca indica, Nyctanthes arbortristis, and Clitoria ternatea extracts against three mosquito vector species. Parasitology Research 104: 1017-1025.

Mohod SP, Jangde CR, Narnawore SD \& Rant S (2014) Experimental evaluation of analgesic property of bark of skin of Saraca indica (Ashoka) and Shorea robusta (Shal). Journal of Applied Pharmaceutical Science 4(2): 062-065.

Mukherjee PK (2002) Quality control of herbal drugs, an approach to evaluation of botanicals. Business Horizons Pharmaceutical Publishers, New Delhi, pp.198, 356-358.

Nadkarni KM (1982) Indian Materia Medica, Vol 1. Popular Prakashan, Bombay, pp. 1105.

Nawagish M, Ansari SH \& Ahmad A (2007) Preliminary pharmacognostical standardization of Lawsonia inermis Linn. seeds. Research Journal of Botany 2(3): 161-164.

Sarojini N, Manjari SA \& Chandrakanti C (2011) Correlation between phytochemical screening and some biological activity using plant extracts. International Journal of Research in Ayurveda and Pharmacy 4: 1343-1348.

Satyavati GV, Prasad DN, Sen SP \& Das PK (1970) Oxytocic activity of a pure phenolic glycoside (P2) from Saraca indica Linn (Ashoka): a short communication. Indian Journal of Medical Research 58: 660-663.

Shelar DB, Shirote PJ \& Naikwade NS (2010) Anti-inflammatory activity and brine shrimps lethality test of Saraca indica (Linn.) leaves extract. Journal of Pharmacy Research 3: 2004-2006.

Verma A, Jana GK, Chakraborty R, Sen S, Sachan S \& Mishra A (2010) Analgesic activity of various leaf extracts of Saraca indica Linn. Der Pharmacia Lettre 2: 352-357.

Wagner H \& Bladt S (1996) Plants Drug Analysis: A Thin Layer Chromatography Atlas. Springer, Berlin, pp. 306-304.

Warrier PK, Nambiar VPK \& Ramankutty C (1997) Indian Medicinal Plants: A Compendium of 500 species, Vol 5. Orient Longman Ltd., Chennai, pp. 66. 